\title{
Synthesis of $(R)$-Ofloxacin
}

\section{Key words}

\section{(R)-ofloxacin}

flumequine

fluoroquinolones

organocatalysis

Brønsted acid catalyzed transfer

hydrogenation<smiles>CC1=Nc2ccc(F)c(F)c2OC1</smiles>

A

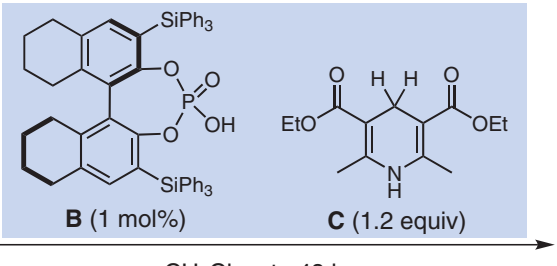

$\mathrm{CH}_{2} \mathrm{Cl}_{2}$, r.t., $48 \mathrm{~h}$ $65 \%$ (er > 96:4), $1.1 \mathrm{mmol}$ scale<smiles>C[C@H]1COc2c(ccc(F)c2F)N1</smiles>

D

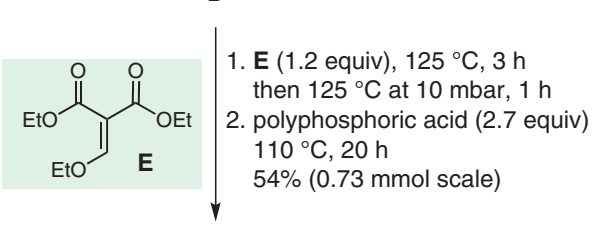<smiles>C[C@@H]1COc2c(N3CCN(C)CC3)c(F)cc3c(=O)c(C(=O)O)cn1c23</smiles>

(R)-Ofloxacin mp not reported
1. $\mathrm{KOH}, \mathrm{THF}-\mathrm{H}_{2} \mathrm{O}$

$70{ }^{\circ} \mathrm{C}, 1.5 \mathrm{~h}$

2. $\mathrm{N}$-methylpiperazine

py, $125^{\circ} \mathrm{C}, 16 \mathrm{~h}$

$53 \%$ (0.37 mmol scale)<smiles>CCOC(=O)c1cn2c3c(c(F)c(F)cc3c1=O)OC[C@H]2C</smiles>

mp $254^{\circ} \mathrm{C}$
Significance: The key step in the small-scale synthesis of $(R)$-ofloxacin depicted here is the first step, a chiral Brønsted acid catalyzed transfer hydrogenation in which the hydride source is the dihydropyridine $\mathbf{c}$. These reactions give excellent enantiofacial discrimination with low catalyst loadings under mild conditions. A synthesis of the simpler fluoroquinolone antibiotic flumequine is also described.
Comment: Ofloxacin is a DNA gyrase inhibitor that was initially marketed as a racemate. The $(S)$-(-)-enantiomer, levofloxicin, is more active than the $(R)$-enantiomer and has now supplanted the racemate for the treatment of life-threatening bacterial infections.

Review: For a review about asymmetric Brønsted acid catalyzed transfer hydrogenations, see: M. Rueping, E. Sugiono, F. R. Schoepke Synlett 2010, 852-865. 